\title{
Increased isoprostanoid levels in brain from murine model of Krabbe disease - Relevance of isoprostanes, dihomo-isoprostanes and neuroprostanes to disease severity
}

\author{
Cinzia Signorini $^{\mathrm{a}, *}$, Venera Cardile ${ }^{\mathrm{b}, * *}$, Giovanna Pannuzzo ${ }^{\mathrm{b}}$, Adriana Carol Eleonora Graziano ${ }^{\mathrm{b}}$, \\ Thierry Durand ${ }^{c}$, Jean-Marie Galano ${ }^{c}$, Camille Oger $^{c}$, Silvia Leoncini ${ }^{\mathrm{d}}$, Alessio Cortelazzo ${ }^{\mathrm{d}}$, \\ Jetty Chung-Yung Lee ${ }^{\mathrm{e}}$, Joussef Hayek ${ }^{\mathrm{d}}$, Claudio De Felice ${ }^{\mathrm{d}, \mathrm{f}}$

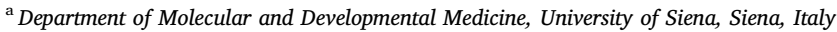 \\ ${ }^{\mathrm{b}}$ Department of Biomedical and Biotechnological Sciences, Sect. of Physiology, University of Catania, Italy \\ ${ }^{\mathrm{c}}$ Institut des Biomolécules Max Mousseron, (IBMM), UMR 5247, CNRS, Université de Montpellier, ENSCM, Montpellier, France \\ ${ }^{\mathrm{d}}$ Child Neuropsychiatry Unit, Azienda Ospedaliera Universitaria Senese, Siena, Italy \\ ${ }^{\mathrm{e}}$ The University of Hong Kong, School of Biological Sciences, Hong Kong Special Administrative Region \\ ${ }^{\mathrm{f}}$ Neonatal Intensive Care Unit, Azienda Ospedaliera Universitaria Senese, Siena, Italy
}

\section{A R T I C L E I N F O}

\section{Keywords:}

Adrenic acid

Isoprostanes

Krabbe disease

Leukodystrophy

Murine models

Neuroprostanes

Oxidative stress

\begin{abstract}
A B S T R A C T
Krabbe disease (KD) is a rare and devastating pediatric leukodystrophy caused by mutations in the galactocerebrosidase (GALC) gene. The disease leads to impaired myelin formation and extensive myelin damage in the brain. Oxidative stress is implicated in the pathogenesis of $\mathrm{KD}$ but insofar few information is available.

The gray and white matter of the brain are rich in docosahexaenoic acid and adrenic acid respectively and under non-enzymatic oxidative stress, release isoprostanoids, i.e. $\mathrm{F}_{4}$-neuroprostanes $\left(\mathrm{F}_{4}\right.$-NeuroPs) and $\mathrm{F}_{2}$-dihomo-isoprostanes ( $\mathrm{F}_{2}$-dihomo-IsoPs).

In this study, the formation of isoprostanoids in brain tissue was investigated in a well-established KD mouse model (twitcher) that recapitulates the human pathology.

According to the genotype determinations, three groups of mice were selected: wild-type control mice $(n=13)$, heterozygotes mice (carriers of GALC mutations, $n=14$ ) and homozygous twitcher mice $(n=13)$. Measurement of $\mathrm{F}_{2}$-dihomo-IsoP and $\mathrm{F}_{4}$-NeuroP levels were performed on whole brain tissue obtained at day 15 and day 35 of the life cycle.

Brain isoprostanoid levels were significantly higher in the twitcher mice compared to the heterozygous and wild-type control mice. However, $\mathrm{F}_{2}$-dihomo-IsoP and $\mathrm{F}_{4}$-NeuroP levels did not differ in brain of day 15 compared to day 35 of the heterozygote mice. Interestingly, isoprostanoid levels were proportionally enhanced with disease severity $\left(\mathrm{F}_{2}\right.$-dihomo-IsoPs, $r h o=0.54 ; \mathrm{F}_{4}$-NeuroPs, $r h o=0.581 ; \mathrm{P}$ values $\left.\leq 0.05 ; \mathrm{n}=13\right)$.

Our findings are the first to show the key role of polyunsaturated fatty acid oxidative damage to brain grey and white matter in the pathogenesis and progression of KD. This shed new insights on the biochemical indexes of KD progression, and potentially provide information for novel therapeutic targets.
\end{abstract}

\section{Introduction}

Krabbe disease (KD) is a rare autosomal recessive disorder attributed to mutations in the galactosylceramidase (GALC) gene. It is also known as globoid cell leukodystrophy due to the presence of multinucleated macrophages (globoid cells) in the brain white matter

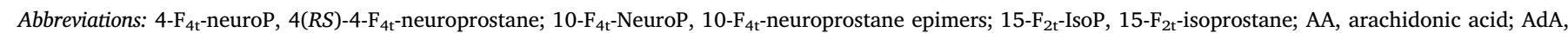

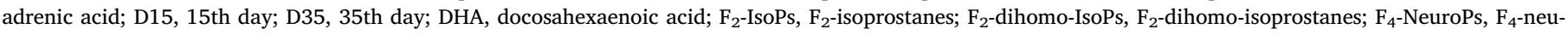

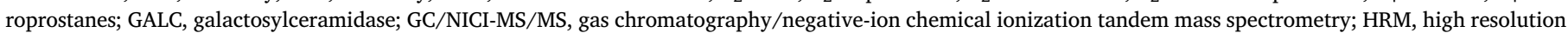
melting; KD, Krabbe disease; PUFA, polyunsaturated fatty acid; ROC, receiver operating characteristic

* Corresponding author.

** Corresponding author.

E-mail addresses: cinzia.signorini@unisi.it (C. Signorini), cardile@unict.it (V. Cardile), c.defelice@ao-siena.toscana.it (C. De Felice). 
and leukodystrophy gliosis. As a consequence, GALC enzymatic deficiency occurs and the metabolite psychosine (galactosylsphingosine) is accumulated [1,2]. Furthermore, increased amounts in unmetabolized galactocerebroside have been proposed to be cytotoxic to oligodendrocytes, which are the myelin-producing cells of the central nervous system [3,4]. Nevertheless, the exact mechanism of such cytotoxicity has not yet been fully elucidated but latest report suggests to take part in activating the immune system and neuroinflammation [5].

Additionally, phospholipase $\mathrm{A}_{2}$ activity has been showed to mediate psychosine-mediated accumulation of lysophosphatidylcholine and release arachidonic acid (AA), and subsequently cause oligodendroyte cell death [6]. Also, increasing evidence strengthens the relevance of polyunsaturated fatty acids (PUFA), namely AA, as well as docosahexaenoic acid (DHA) and adrenic acid (AdA) to brain physiology and development [7-14].

Recently, brain fatty acid composition was investigated in KD using the twitcher mice [15] and it showed to be altered, which could reflect the underlying metabolic changes taking place during disease progression [16].

It is well known that the non-enzymatic oxidation of AA, DHA, and AdA, are involved in clinical and experimental neurological disease [17-19] by the generation of prostaglandin isomers termed isoprostanoids [20]. Oxidative stress stimulates reactive oxygen species (ROS)/free-radical mediated peroxidation of AA, DHA and AdA and consequently leads to the formation of isoprostanoids namely $\mathrm{F}_{2}$-isoprostanes $\left(\mathrm{F}_{2}\right.$-IsoPs), $\mathrm{F}_{4}$-neuroprostanes $\left(\mathrm{F}_{4}\right.$-NeuroPs $)$ and $\mathrm{F}_{2}$-dihomoisoprostanes ( $\mathrm{F}_{2}$-Dihomo-IsoPs), respectively. Both isoprostanes (IsoPs) and neuroprostanes (NeuroPs) are well described biomarkers of oxidative stress and may participate in cellular signaling [21-24]. Moreover, $\mathrm{F}_{4}$-NeuroPs and $\mathrm{F}_{2}$-dihomo-IsoPs are advocated to be associated to gray and white brain matter oxidative damage, respectively [25,26]. Moreover, DHA is highly concentrated in neuronal membranes and $\mathrm{F}_{4^{-}}$ NeuroPs are by far the most abundant products of DHA peroxidation in the brain [27], whereas AdA is ubiquitously distributed in the body, but also a specific component of myelin in the brain of primates [28].

To the best of our knowledge, the formation and role of isoprostanoids in KD are unknown despite oxidative stress related pathways have been proposed for therapeutic target [2,29-32].

The purpose of the study is to investigate the possible involvement of IsoPs, dihomo-IsoPs and NeuroPs in the KD pathogenesis taking into account that DHA and AdA are specifically distributed in the brain and the distribution of these specific isoprostanoids derived from the nonenzymatic oxidation process is relevant to the disease progression.

\section{Materials and methods}

\subsection{Animals}

The animal handling protocol was approved by the Institutional Animal Care and Use Committee for this study in accordance with institutional guidelines for animal care and use (Project no. 278; authorization no. 1123/2016-PR; 2016/11/22).

Pairs of twitcher heterozygotes mice, a strain that contains a premature stop codon $(\mathrm{W} 339 \times)$ in the galactosylceramidase (GALC) gene that inhibits enzymatic activity [33-35], were maintained in the housing facility. The mice were housed in plastic cages in pathogen-free room with controlled temperature $\left(22 \pm 2{ }^{\circ} \mathrm{C}\right)$, relative humidity $(45 \pm 5 \%)$ and $12 / 12 \mathrm{~h} \mathrm{light/dark} \mathrm{cycle.} \mathrm{Food} \mathrm{and} \mathrm{water} \mathrm{were} \mathrm{avail-}$ able ad libitum and the cages were cleaned once-twice a week.

\subsection{Genotyping}

The genomic DNA of 10-12 days old pups born from twitcher heterozygotes was extracted from clipped tails according to the method provided by the kit manufacturer (Sigma Aldrich, Milan, Italy).

The genotypes were determined by high resolution melting (HRM) post-polymerase chain reaction (PCR) analysis to identify variations in the nucleic acid sequences. Genomic DNA was amplified according to the manufacturer's protocol of Type-it HRM PCR kit (Qiagen, Milan, Italy). Aliquots of genomic DNA were amplified using the following specific 5'ATCAGACTGAAATTGGTAGACAGC-3' for forward and 5'-GCCATCAGTCAGAGCAACATAAC-3' for reverse primers.

The analysis was performed on Rotor-gene Q real-time analyzer (Corbett, Qiagen, Milan, Italy). The amplification protocol included an initial denaturation at $95^{\circ} \mathrm{C}$ for $5 \mathrm{~min}$, followed by 40 cycles at $95^{\circ} \mathrm{C}$ for $10 \mathrm{~s}, 55^{\circ} \mathrm{C}$ for $30 \mathrm{~s}$, and $72^{\circ} \mathrm{C}$ for $10 \mathrm{~s}$. The melting analysis was performed after cycling first heating to $95^{\circ} \mathrm{C}$ for $5 \mathrm{~min}$, cooling to $40^{\circ} \mathrm{C}$ for $1 \mathrm{~min}$, heating again to $65^{\circ} \mathrm{C}$ (all at $20^{\circ} \mathrm{C} / \mathrm{s}$ ), and then melting at $0.1^{\circ} \mathrm{C} /$ $\mathrm{s}$ with continuous acquisition of fluorescence until $95^{\circ} \mathrm{C}$. The Rotor gene $\mathrm{Q}$ software was used to calculate the derivative melting curves.

\subsection{Scoring system of disease severity}

In the life cycle of Krabbe-affected mice, clinical symptoms develop at the onset of the active myelination period and if untreated, they die at $35 \pm 2$ days. Therefore, for the experimentations, two different times of sacrifice were selected: one before the onset of symptoms (15th day, D15) and another at the terminal course of the disease (35th day, D35). The first group included six wild-type, seven heterozygous and six twitcher mice (sacrificed on D15). The second group comprised of seven wild-type, seven heterozygous and seven twitcher mice (sacrificed on D35).

During this period, starting from 8th day, the animals were monitored every 3-4 days by recording the body weight and scored for their response to coordination, hindlimb clasping and gait. The person who monitored the mice and undertook the behavioral evaluations was blinded to the genotype of the mice.

To quantify the disease severity, we used a scoring system that consists of scale 0 to 4 , with 0 representing absence of the relevant KD phenotype and 4 representing the most severe manifestation. Each test was performed multiple times to ensure that the score was consistent.

Hind limb clasping is an indicator for disease progression. The mouse tail was grasped near its base, it was lifted in a space without any obstructing objects in the surrounding and the hind limb position was observed for $10 \mathrm{~s}$. If the hind limbs were consistently splayed outward, away from the abdomen, it was assigned a score 0 . If the hind limbs were entirely retracted and touching the abdomen for more than $75 \%$ of the time suspended, it received a score 4 . Coordination and muscle function were assessed by the gait. The mouse was removed from its cage and placed on a flat surface with its head facing away from the investigator. Afterward, the assessor observed as it walked. If the mouse moved normally, with its body weight supported on all limbs, and its abdomen not touching the ground, it received a score of 0 . If the mouse had difficulty moving forward and dragged its abdomen along the ground, it received a score of 4 .

These procedures are capable of detecting disease severity differences between strains and within the same strain over time. The measurements collected were combined and analyzed for the composite phenotype score of each individual mouse (Table 1).

\subsection{Brain tissue collection}

On D15 and D35, the anesthetized mouse was placed in a heated cage for 5-10 min and first assessed for the responses to tail/toe pinches and the intactness of the ocular reflex. When the mouse is unresponsive to the noxious stimuli and the reflex is absent, it was fixed in the supine position (lying on the back with face upward) by gently tapping the forepaws and hind paws to a work surface. Thereafter, the skin was incised with surgical scissors along the thoracic midline where the thoracic field is exposed completely. The diaphragm was separated from the chest wall on both sides with scissor cuts to expose the heart. The right atrium was cut with scissors and at the first sign of blood flow, 
Table 1

Scoring criteria of the KD mice in the study.

\begin{tabular}{|c|c|c|}
\hline Phenotype score & Main Phenotypic signs & Phenotype description \\
\hline $\mathbf{0}$ & No clinical sign, normal feeding, normal gait. & $\begin{array}{l}\text { The mouse moves normally, with its body weight supported on all limbs, with its } \\
\text { abdomen not touching the ground, and with both hind limbs participating evenly, and } \\
\text { consistently splayed outward, away from the abdomen. }\end{array}$ \\
\hline 1 & Slight tremor, normal feeding, almost normal gait. & $\begin{array}{l}\text { The mouse appears to limp while walking, with one hind limb retracted toward the } \\
\text { abdomen for less than } 50 \% \text { of } 10 \mathrm{~s} \text {. }\end{array}$ \\
\hline 2 & Accentuate tremor and limp, slight weight loss, normal feeding. & $\begin{array}{l}\text { The mouse manifests continuous trembling when it is stationary and both hind limbs } \\
\text { are partially retracted toward the abdomen for less than } 50 \% \text { of } 10 \mathrm{~s} \text {. }\end{array}$ \\
\hline 3 & $\begin{array}{l}\text { Severe tremor, paresis of the hind limbs, weight loss equal to or } \\
\text { slightly higher than } 20 \% \text {, feeding with food and water placed on the } \\
\text { floor of the cage. }\end{array}$ & $\begin{array}{l}\text { The mouse presents an uncoordinated movement and both hind limbs are partially } \\
\text { retracted toward the abdomen for more than } 50 \% \text { of } 10 \mathrm{~s} \text {. }\end{array}$ \\
\hline 4 & $\begin{array}{l}\text { Paralyzed hind limbs, general weakness, weight loss higher than } 20 \% \text {, } \\
\text { feeding with extreme difficulty }\end{array}$ & $\begin{array}{l}\text { The mouse has difficulty moving, it drags its abdomen along the ground, and both } \\
\text { hind limbs are retracted toward the abdomen for the time suspended of } 10 \mathrm{~s} \text {. }\end{array}$ \\
\hline
\end{tabular}

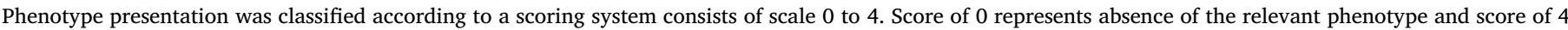
represents the most severe manifestation.

the infusion of phosphate-buffered saline (PBS, pH 7.4) was started. Perfusion was continued until the fluid exiting the right atrium was entirely clear. Afterward, the brain tissues were removed and bisected on the sagittal plane. The brain tissues were immediately frozen on dry ice and stored at $-80^{\circ} \mathrm{C}$ for further assays.

\subsection{Isoprostanoid determination}

\subsubsection{Sample preparation}

The brain tissue samples were homogenized $(10 \% \mathrm{w} / \mathrm{v})$ in PBS (pH 7.4) and then hydrolyzed by incubating the brain tissue homogenate $(1 \mathrm{ml})$ in aqueous $\mathrm{KOH}(1 \mathrm{mM}, 500 \mu \mathrm{l})$ at $45^{\circ} \mathrm{C}$ for $45 \mathrm{~min}$. Afterward, the $\mathrm{pH}$ of the mix was adjusted to 3 by adding $\mathrm{HCl}(1 \mathrm{mM}, 500 \mu \mathrm{l})$. Each sample was spiked with tetra-deuterated prostaglandin $\mathrm{F}_{2 \alpha}\left(\mathrm{PGF}_{2 \alpha}-\mathrm{d}_{4}\right)$ ( $500 \mathrm{pg}$ in $50 \mu \mathrm{l}$ of ethanol), as the internal standard. Ethyl acetate $(10 \mathrm{ml})$ was added to extract total lipids by vortex-mixing and centrifugation at $1000 \times g$ for $5 \mathrm{~min}$ at room temperature. The lipid extract was purified using solid phase extraction (SPE) as follows. Each total lipid extract was transferred to an $\mathrm{NH}_{2}$ cartridge ( $500 \mathrm{mg}$ Sorbent per Cartridge, 55-105 $\mu \mathrm{m}$ Particle Size, $6 \mathrm{cc}$, Waters, USA) preconditioned with hexane $(5 \mathrm{ml})$. After loading, each $\mathrm{NH}_{2}$ cartridge was sequentially washed with $10 \mathrm{ml}$ of hexane:ethyl acetate $(30: 70, \mathrm{v} / \mathrm{v}), 10 \mathrm{ml}$ acetonitrile:water $(9: 1, \mathrm{v} / \mathrm{v})$ and $10 \mathrm{ml}$ acetonitrile. The final elution was collected using a mix of ethyl acetate:methanol:acetic acid (10:85:5, v/ $\mathrm{v} / \mathrm{v}, 5 \mathrm{ml}$ ) and then dried under nitrogen at $40^{\circ} \mathrm{C}$ and derivatized for gas chromatography/negative ion chemical ionization tandem mass spectrometry (GC/NICI-MS/MS) analysis. In brief, the carboxylic group was converted into pentafluorobenzyl ester in the derivatization process by incubating the sample at $40^{\circ} \mathrm{C}$ for $45 \mathrm{~min}$ with pentafluorobenzyl bromide ( $40 \mu \mathrm{l}, 10 \%$ in acetonitrile) and diisopropylethylamine ( $20 \mu 1,10 \%$ in acetonitrile). Thereafter, it was evaporated under nitrogen, and the hydroxyl groups were converted to trimethylsilyl ethers by incubating with $50 \mu \mathrm{l}$ of N,O-bis (trimethylsilyl) trifluoroacetamide and $5 \mu \mathrm{l}$ of diisopropylethylamine (10\% in acetonitrile) for $1 \mathrm{~h}$ at $45^{\circ} \mathrm{C}[36-38]$.

\subsubsection{Gas chromatography/negative ion chemical ionization tandem mass} spectrometry (GC/NICI-MS/MS) analysis

The derivatized sample was injected ( $2 \mu \mathrm{l})$ for GC/NICI-MS/MS analysis. Briefly, the gas chromatograph (Trace GC and PolarisQ, Thermo/Finnigan, USA) was set at splitless mode ( $2 \mathrm{~min})$ and the oven temperature was increased from $175^{\circ} \mathrm{C}$ to $270^{\circ} \mathrm{C}\left(30^{\circ} \mathrm{C} / \mathrm{min}\right)$. Helium was used as the carrier gas $(1 \mathrm{ml} / \mathrm{min})$ and the chromatography was performed using a SPB $1701 \mathrm{GC}$ capillary column $(30 \mathrm{~m} \times 0.25 \mathrm{~mm}$ i.d., $0.25 \mu \mathrm{m}$ film thickness, Supelco, USA). The reagent gas for the chemical ionization was methane set to $2.0 \mathrm{ml} / \mathrm{min}$ flow rate.

For total $\mathrm{F}_{2}$-IsoP (free plus esterified) measurements, it is based on $15-\mathrm{F}_{2 \mathrm{t}}$-IsoP which is one of the most represented isomers of the $\mathrm{F}_{2}$-IsoPs
[36,37]. In the analysis, the product ion was $m / z 299$ derived from $[\mathrm{M}-181]^{-}$of the precursor ion $(\mathrm{m} / z 569)$.

As for $4(R S)-\mathrm{F}_{4 \mathrm{t}^{-}}-$NeuroP $\left(4-\mathrm{F}_{4 \mathrm{t}}-\mathrm{NeuroP}\right)$ and $10(R)-10-\mathrm{F}_{4 \mathrm{t}^{-}}$ NeuroP $+10(S)-10-\mathrm{F}_{4 \mathrm{t}}-$ NeuroP $\left(10-\mathrm{F}_{4 \mathrm{t}}-\right.$ NeuroP) the product ion was $m / z 323$ derived from $[\mathrm{M}-181]^{-}$of the precursor ions $(\mathrm{m} / \mathrm{z} 593)$ [38].

Total $\mathrm{F}_{2}$-dihomo-IsoP (ent-7 $(R S)$ - $\mathrm{F}_{2 \mathrm{t}}$-dihomo-IsoP $+17-\mathrm{F}_{2 \mathrm{t}}$-dihomoIsoP) measurement was made by identification of the product ion $\mathrm{m} / \mathrm{z}$ 327 derived from $[\mathrm{M}-181]^{-}$ion of the precursor ion $(m / z 597)$ [39].

As for the internal standard, the product ion $m / z 303$, derived from $[\mathrm{M}-181]^{-}$of the precursor ion $(m / z 573)$, was detected and referred to the internal standard $\mathrm{PGF}_{2 \alpha}-\mathrm{d}_{4}[36,38,39]$.

Isoprostanoids quantification were carried out by relating the isoprostanoid/internal standard peak area ratio of the calibration curves constructed. The concentration points of the curve ranged from $50 \mathrm{pg} /$ $\mathrm{ml}$ to $2 \mathrm{ng} / \mathrm{ml}$ of $15-\mathrm{F}_{2 \mathrm{t}}$-IsoPs, $4-\mathrm{F}_{4 \mathrm{t}}$-NeuroP, $10-\mathrm{F}_{4 \mathrm{t}}$-NeuroP, ent-7(RS)$\mathrm{F}_{2 \mathrm{t}}$-dihomo-IsoP, or $17-\mathrm{F}_{2 \mathrm{t}}$-dihomo-IsoP, with $500 \mathrm{pg} \mathrm{PGF}_{2 \alpha}-\mathrm{d}_{4}$ internal standard. All samples derivatized were measured by GC/NICI-MS/MS. For each brain tissue measured, the concentration of the isoprostanoid was expressed as gram of tissue.

\subsection{Chemical synthesis of $4-F_{4 t}$-NeuroP, $10-F_{4 t}$-NeuroP, and $F_{2}$-dihomo-} IsoP reference molecules

2.6.1. $4(R S)-F_{4 t^{-}}$NeuroP, and $10(R)-10-F_{4 t^{-}}$NeuroP and $10(S)-10-F_{4 t^{-}}$ NeuroP synthesis

As reported [40,41], NeuroPs and dihomo-IsoPs were in-house synthesized by Institut des Biomolécules Max Mousseron (IBMM, France). Among all the $\mathrm{F}_{4}$-NeuroPs isomers that can be formed from non-enzymatic DHA oxidation, $4(R S)-4-\mathrm{F}_{4 \mathrm{t}}-$ NeuroP $\left(4-\mathrm{F}_{4 \mathrm{t}}-\mathrm{NeuroP}\right)$ and $10(R)-10-\mathrm{F}_{4 \mathrm{t}}-$ NeuroP $+10(S)-10-\mathrm{F}_{4 \mathrm{t}}-$ NeuroP $\left(10-\mathrm{F}_{4 \mathrm{t}}-\right.$ NeuroP) are the most represented and their clinical relevance in different neurological diseases has been recently demonstrated [38,42].

\subsection{Statistical analysis}

Statistical analysis was performed using the statistical software package SYSTAT, version 11 (Systat Inc., Evanston, IL, USA), and MedCalc ver. 12.0 (MedCalc. Software, Mariakerke, Belgium). Data distribution for quantitative variables was tested for normal fit (D'Agostino-Pearson test). On account of normal and non-normal data distribution, differences between groups were tested by Student's t-test, Kruskal-Wallis test, one-way analysis of variance (ANOVA), Dunnett's test, Scheffé test for all pairwise comparisons and post-hoc analyses were made. The association between variables was tested using both Spearman rank and Kendall's rank correlation tests at 95\% confidence intervals (95\% C.I.) for rho and Tau coefficient, respectively. Value level of $\mathrm{P} \leq 0.05$ was considered statistically significant. The receiver 


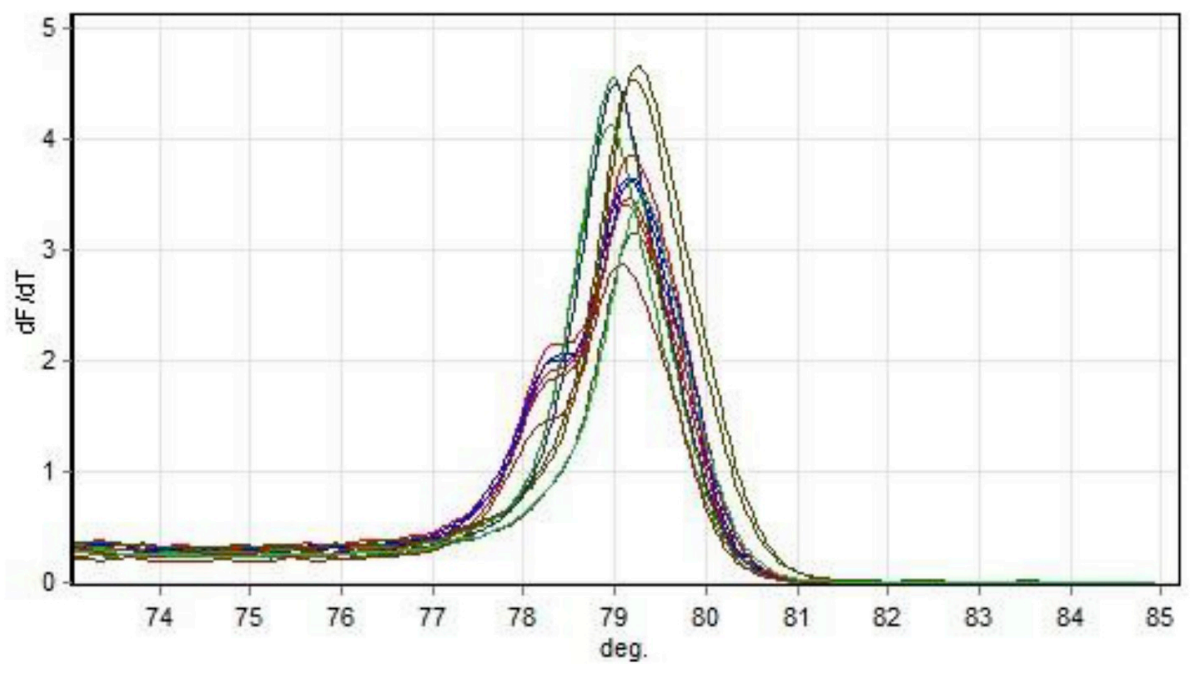

Fig. 1. Melting curves $(\mathrm{dF} / \mathrm{dT})$ derivative of highresolution melting (HRM): $d F / d T$ means change in fluorescence level with increase per unit temperature change $\left({ }^{\circ} \mathrm{C}\right)$. Homoduplex on the right side of the graphic represents twitcher mice; Homoduplex on the left side of the graphic represents wild-type mice; Heteroduplex represents heterozygous mice.

operating characteristic (ROC) curve analysis was performed for isoprostanoid levels measured in brain tissues to estimate the discriminative power regarding to mouse severity score.

\section{Results}

\subsection{Genotyping}

The genotypes were determined by HRM analysis. This technique allowed to distinguish the differences of DNA sequence by analyzing the melting curve path. Each duplex (homoduplex or heteroduplex) exhibited a characteristic melting curve path (Fig. 1). As shown, homoduplex of the right part of the graph confirms the genotype of twitcher mice and the left side the wild-type, and the heteroduplex of the graph affirms the genotype of the heterozygouse mice. Accordingly, the mice were then divided into three groups, wild-type control mice $(n=13)$, heterozygotes mice (carriers of GALC mutations, $n=14$ ) and homozygous twitcher mice $(n=13)$ for further evaluation.

\subsection{Disease severity scoring}

According to the scoring criteria (Table 1), the disease severity was quantified. In twitcher mice, the disease severity was progressive and significant increase from day 8 onwards $(\mathrm{P}<0.001)$ was found. In particular, the first increase in the clinical severity scores were noticeable on day 18 , where the severity score was significantly different from those measured at days 8 and $11(\mathrm{P}<0.05)$. A higher disease severity score (4.0) was observed in twitcher mice at day 35. Throughout the experimental period, all wild-type and heterozygous mice were healthy and showed normal weight increase (score 0) (Fig. 2).

\subsection{Levels of isoprostanoids in brain tissues}

The GC/NICI-MS/MS detection of $15-\mathrm{F}_{2 \mathrm{t}}$-IsoPs, $4-\mathrm{F}_{4 \mathrm{t}}$-NeuroP, 10 $\mathrm{F}_{4 \mathrm{t}}$-NeuroP, ent-7(RS)- $\mathrm{F}_{2 \mathrm{t}}$-dihomo-IsoP and $17-\mathrm{F}_{2 \mathrm{t}}$-dihomo-IsoP was carried out in all brain samples from wild-type, heterozygous and twitcher mice.

A significant elevated concentration of $\mathrm{F}_{2}$-IsoPs in brain tissue of the twitcher mice was found compared to wild-type and heterozygous mice The concentration increased according to the mice phenotype where it was found to be in the following order: twitcher > heterozygous > wild-type. It is known AA is outspread in the brain white and grey matter, and any changes related to AA oxidation indicates overall oxidative damage in the brain. Our observation showed subclinical AA non-enzymatic oxidation took place in the heterozygous and twitcher

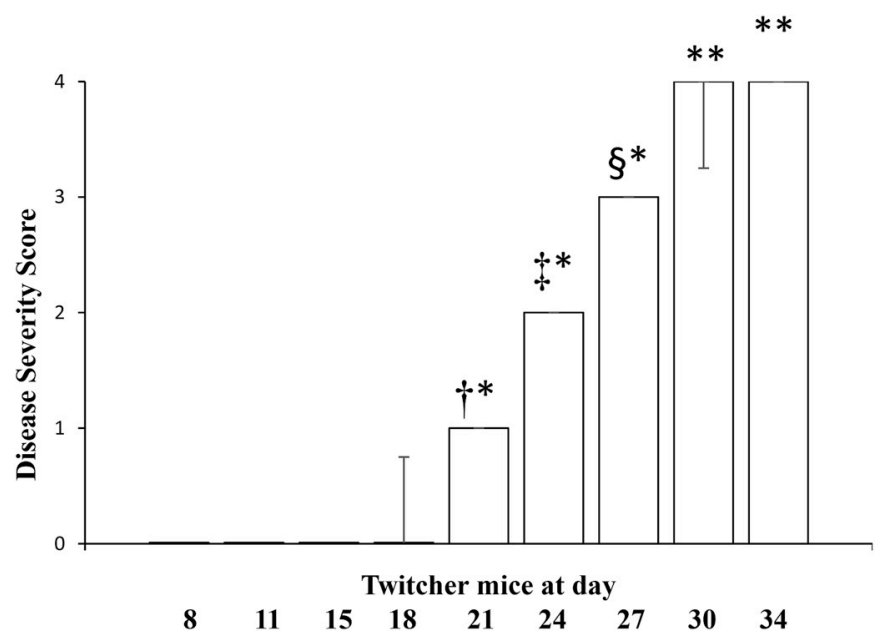

Fig. 2. Disease severity in twitcher mice from day 8 to day 34 . Data are expressed as medians (columns); bars are inter-quartile ranges (25th-75th percentiles). Kruskal-Wallis test, $\mathrm{P}<0.00001$. Legends: ** statistically different from days $8,11,15,18,21,24$ and $27 ; *$ statistically different from day $8,11,15,18$; $\uparrow$ statistically different from days 24 and $27 ; \div$ statistically different from days 21 and 27; § statistically different from days 21 and 24 . No variability in severity score was observed at days $8,11,15,21,24,27$ and 34 .

mice, since $\mathrm{F}_{2}$-IsoP levels in the brain were significantly higher than those detected in wild-type mice $(\mathrm{P}<0.05)$. The level of augmentation was significantly higher in the twitcher mice compared to heterozygous mice $(\mathrm{P}<0.05)$ (Fig. 3). There was no difference between D15 and D35 levels for all mice type.

Interestingly, $\mathrm{F}_{2}$-dihomo-IsoP levels compared to $\mathrm{F}_{2}$-IsoP levels appeared to be more prominent and distinctively related to KD symptoms. Higher $\mathrm{F}_{2}$-dihomo-IsoP levels in twitcher mice brain tissues were observed at D35 as compared to those of heterozygous and wild-type at D15 and D35 $(P<0.05)$. No significant difference was detected for $F_{2-}$ dihomo-IsoP levels between wild-type and heterozygous mice brain tissues, and between D15 and D35 of the respective type (Fig. 3). Regardless of the distinctive days of the disease progression and by grouping the mice according to the genotype namely wild-type, heterozygous, and twitcher alone, $\mathrm{F}_{2}$-dihomo-IsoP levels were significantly higher in the brain tissues of twitcher mice compared to both wild-type and heterozygous mice (ANOVA test, $\mathrm{P}<0.001$; Scheffé test for all pairwise comparisons, $\mathrm{P}<0.05$ ). However, $\mathrm{F}_{2}$-dihomo-IsoP levels showed no significant difference between heterozygous and wild-type mice (data not shown). 
A

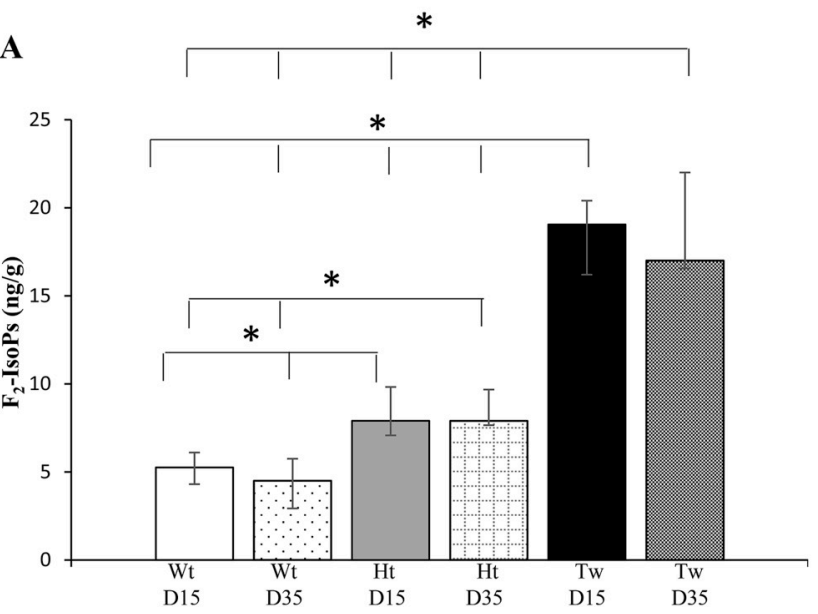

B

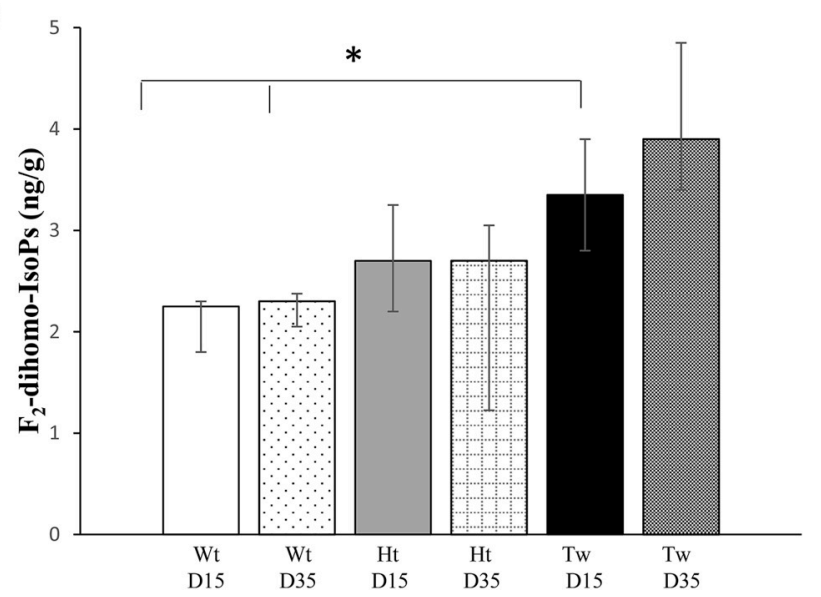

Fig. 3. $F_{2}$-IsoP and $F_{2}$-dihomo-IsoP levels in whole brain tissue from wild-type, heterozygote and homozygous twitcher mice at day 15 and day 35 of the life cycle, respectively.

Panel A: Kruskal-Wallis test, $\mathrm{P}<0.0001$; Panel B: Kruskal-Wallis test, $\mathrm{P}<0.01$.

Data $(n=40)$ are expressed as medians (columns); bars are inter-quartile ranges (25th-75th percentiles). Asterisks indicate significant pairwise tests, $\mathrm{P}<0.05$. Wt: wild-type; Ht: heterozygote; Tw: twitcher; D15: day 15; D35: day 35.
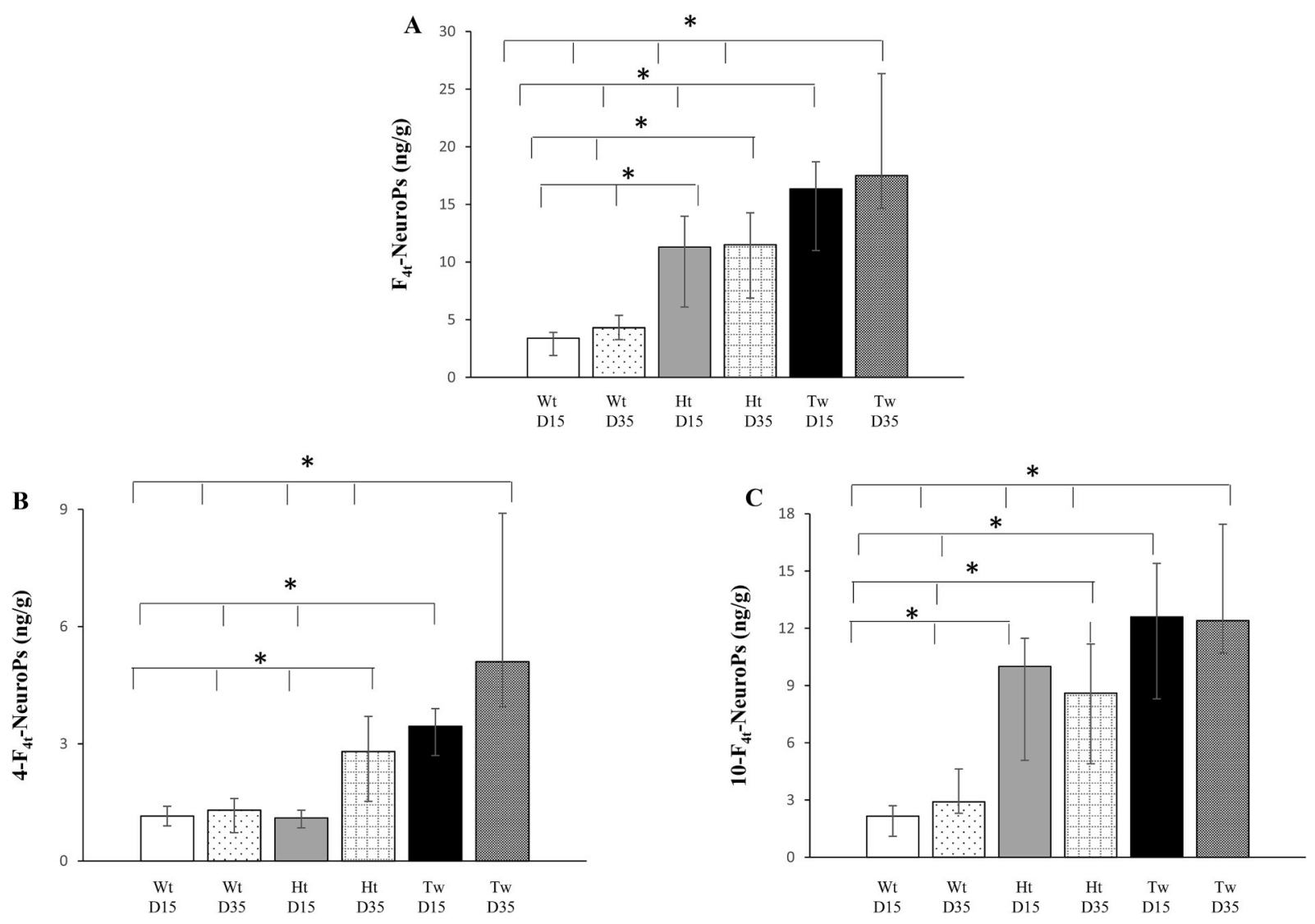

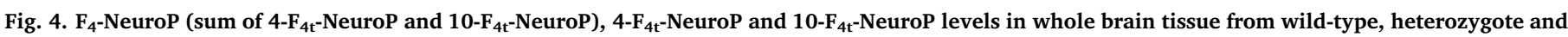
homozygous twitcher animals at day 15 and day 35 of the life cycle, respectively.

Panel A: Kruskal-Wallis test, $\mathrm{P}=0.0001$; Panel B: Kruskal-Wallis test, $\mathrm{P}=0.0001$; Panel C: Kruskal-Wallis test, $\mathrm{P}=0.0001$.

Data $(n=40)$ are expressed as medians (columns); bars are inter-quartile ranges (25th-75th percentiles). Asterisks indicate significant pairwise tests, $\mathrm{P}<0.05$. Wt: wild-type; Ht: heterozygote; Tw: twitcher; D15: day 15; D35: day 35.

The concentration of $\mathrm{F}_{4}$-NeuroPs in the brain tissues differed between the mice symptoms where it was found to be twitcher $>$ heterozygous $>$ wild-type. Total, $\mathrm{F}_{4}-\mathrm{NeuroP}\left(4-\mathrm{F}_{4 \mathrm{t}^{-}} \mathrm{NeuroP}+10-\mathrm{F}_{4 \mathrm{t}^{-}}\right.$ NeuroP) brain tissue levels were significantly higher in twitcher mice at
D35 as compared to D15 and D35 wild-type and heterozygous mice. The levels of $\mathrm{F}_{4}$-NeuroP in the brain tissue did not differ in the disease progression (D15 vs D35) for all mice genotypes (Fig. 4). When differentiating the isomeric type for $\mathrm{F}_{4}$-NeuroPs, the concentration of 4- $\mathrm{F}_{4 \mathrm{t}^{-}}$ 
NeuroP and $10-\mathrm{F}_{4 \mathrm{t}}$-NeuroP at D15 and D35 in twitcher mice were not statistically different. In the brain tissues of heterozygous mice, $4-\mathrm{F}_{4 \mathrm{t}^{-}}$ NeuroP levels were significantly different between D15 and D35 whereas no difference was found for $10-\mathrm{F}_{4 \mathrm{t}}$-NeuroP levels. However, concentrations of $10-\mathrm{F}_{4 \mathrm{t}}$-NeuroP in the brain tissues of all mice genotypes were $2-3$ folds higher than $4-\mathrm{F}_{4 \mathrm{t}}-\mathrm{NeuroP}$. In addition, regardless of the distinctive days of the disease progression and by grouping the mice according to wild-type, heterozygous, and twitcher genotypes, the brain tissues of twitcher mice had significantly higher $4-\mathrm{F}_{4 \mathrm{t}}$-NeuroP and $10-\mathrm{F}_{4 \mathrm{t}}$-NeuroP levels compared to heterozygous and wild-type (ANOVA test, $\mathrm{P}<0.001$; Scheffé test for all pairwise comparisons, $\mathrm{P}<0.05$ ). Further for $10-\mathrm{F}_{4 \mathrm{t}}$-NeuroP levels, statistical significance was found between wild-type and heterozygous mice type (ANOVA test, $\mathrm{P}<0.001$; Scheffé test for all pairwise comparisons, $\mathrm{P}<0.05$ ) but not for $4-\mathrm{F}_{4 \mathrm{t}^{-}}$ NeuroP levels (data not shown).

The following isoprostanoid levels were found to be significantly correlated to each other: $\mathrm{F}_{2}$-IsoPs $v s$ total $\mathrm{F}_{4}$-NeuroPs $(r h o=0.598$, $\mathrm{P}<0.0001$, 95\% C.I. for rho: 0.352 to 0.766 ; Kendall's Tau coefficient $=0.417, \mathrm{P}=0.0002,95 \%$ C.I. for Tau: 0.233 to $0.570 ; \mathrm{n}=40$ ); $\mathrm{F}_{2}$-IsoPs $v s$ total $\mathrm{F}_{2}$-dihomo-IsoPs $(r h o=0.440, \mathrm{P}=0.0045,95 \%$ C.I. for rho: 0.149 to 0.661 ; Kendall's Tau coefficient $=0.330, \mathrm{P}=0.0028$, $95 \%$ C.I. for Tau: 0.0788 to $0.541 ; \mathrm{n}=40$ ); total $\mathrm{F}_{4}$-NeuroPs $v$ s total $\mathrm{F}_{2^{-}}$ dihomo-IsoPs $(r h o=0.675, \mathrm{P}<0.0001,95 \%$ C.I. for $r h o: 0.460$ to 0.815 ; Kendall's Tau coefficient $=0.510, \mathrm{P}<0.0001,95 \%$ C.I. for Tau: 0.332 to $0.661 ; \mathrm{n}=40$ ).

\subsection{Brain isoprostanoids and disease severity}

Relationships between disease progression and non-enzymatic PUFA oxidation were determined by correlation of disease severity and isoprostanoids levels. In twitcher mice $(\mathrm{n}=13)$, the severity score was significantly correlated to $\mathrm{F}_{2}$-dihomo-IsoPs $(r h o=0.54, \mathrm{P}=0.057$, 95\% C.I. for rho: 0.0163 to 0.841 ; Kendall's Tau coefficient $=0.437$, $\mathrm{P}=0.044,95 \%$ C.I. for Tau: 0.00479 to 0.724 ) and $4-\mathrm{F}_{4 \mathrm{t}}-\mathrm{NeuroPs}$ ( $r h o=0.581, \mathrm{P}=0.037,95 \%$ C.I. for $r h o: 0.044$ to 0.857 ; Kendall's Tau coefficient $=0.481, \mathrm{P}=0.026$, $95 \%$ C.I. for Tau: 0.0157 to 0.822 ) levels in the brain tissues (Fig. 5). No significant correlations with severity score were found for total $\mathrm{F}_{2}$-IsoPs, $10-\mathrm{F}_{4 \mathrm{t}}-\mathrm{NeuroP}$ and total $\mathrm{F}_{4}$ NeuroPs (data not shown).

ROC curve analysis showed significant specificity and sensitivity of each isoprostanoid (total $\mathrm{F}_{2}$-IsoPs, total $\mathrm{F}_{2}$-dihomo-IsoPs, 4- $\mathrm{F}_{4 \mathrm{t}}$-NeuroP, $10-\mathrm{F}_{4 \mathrm{t}}$-NeuroP and total $\mathrm{F}_{4}$-NeuroPs) amount to discriminate mice with severity score $\geq 1$ from those with severity score of 0 . The cut-off value was calculated for each isoprostanoid class. A summary of the test is shown in Table 2.

\section{Discussion}

Activation of the immune system and neuroinflammation are related to the pathogenesis of KD [43-45]. These are sources of ROS and potentially accumulate, leading to oxidative stress. Accordingly, neuroinflammatory processes are suggested to play a key role for oxidative damage to the brain. PUFAs, especially AA, AdA and DHA are rich in the brain and prone to oxidation $[17,22,46,47]$. Depending on the degree of oxidative stress, a mixture of oxidized molecules are released that may be protective, cytotoxic to the neural cells or idle without significant pathogenic purpose. Psychosine-induced damage in KD appears to be redox sensitive and reducible by antioxidant defenses $[48,49]$ and therefore appropriate to consider its relationship with oxidative damage.

Non-enzymatic ROS/free radical oxidation of AA, AdA and DHA release unique set of molecules known as isoprostanoids that potentially serve as phenotypical characterization in neurological diseases $[17,19,22,50,51]$ and in current experimental $\mathrm{KD}$. Specific isoprostanes are released depending on the type of PUFA. Under oxidative stress, AA, which is non-specifically disseminated in the brain, releases $\mathrm{F}_{2}$-IsoPs whereas brain white matter enriched AdA generates $\mathrm{F}_{2}$-dihomo-IsoPs, and DHA brain grey matter enriched DHA releases $\mathrm{F}_{4}$-NeuroPs $[17,22]$.

Esch et al. laid the foundations for a lipidomic approach in KD [52], and further suggested PUFA in the profile can track KD disease progression [16]. Moreover, the relevance of PUFAs to brain function is widely documented [7-9]. Long-chain PUFAs are abundant in brain, and the occurrence of neurogenesis, expansion of glial cells and neurons, as well as nerve myelination, strongly depend on the presence of long-chain PUFAs [10-12]. Among long-chain PUFAs, AA and DHA are essential for neurogenesis and hippocampal development [13,53]. Neuroplasticity and monoaminergic transmission are also closely related to PUFA profile $[10,54,55]$. In addition, fatty acids are required in ceramide formation of the neural cells and alterations of these fatty acids in the myelin lipids have been related to neurological dysfunction $[56,57]$.

In this study, we showed that the twitcher mice were under oxidative stress and that non-enzymatic oxidation of AA, AdA and DHA was consistently notable and the process predominantly occurred for AA and DHA. Our observation also showed oxidative damage took place since a specific relationship between isoprostanoid levels and the KD
A

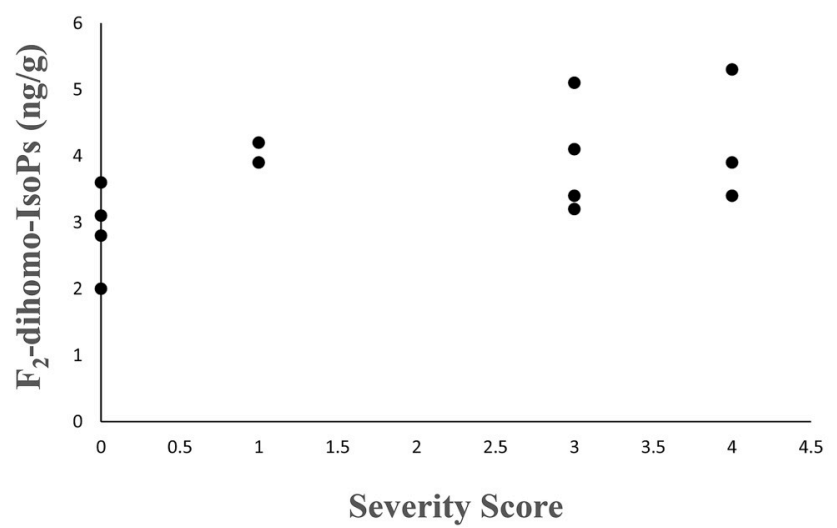

B

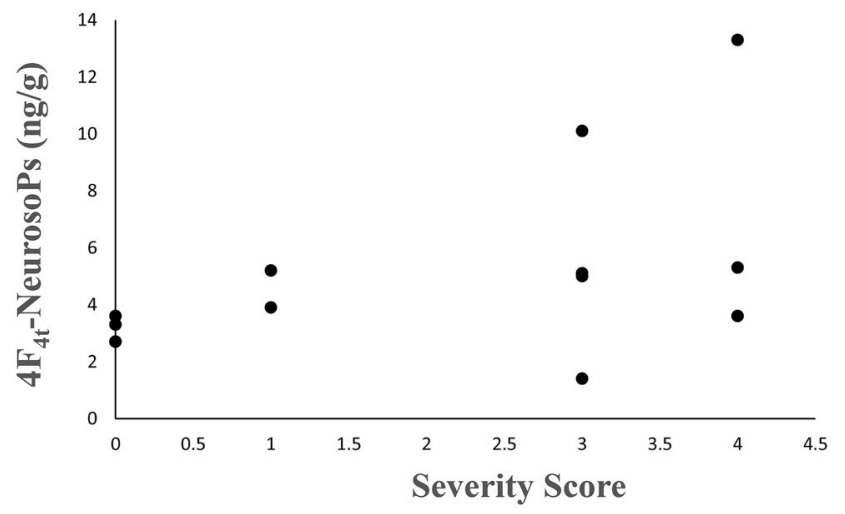

Fig. 5. Relationship between isoprostanoid levels in brain tissue and disease severity.

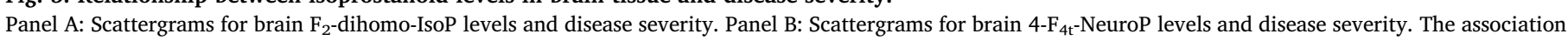

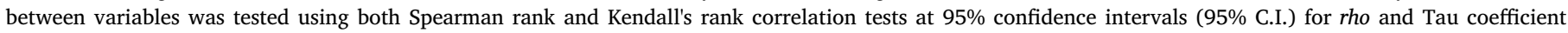
respectively. The parameters of the significant relationships are described in the Results. 
Table 2

ROC analysis for brain isoprostanoid content and disease severity.

\begin{tabular}{|c|c|c|c|c|c|c|}
\hline \multirow[b]{2}{*}{ Isoprostanoid class } & \multicolumn{6}{|c|}{ Mice group with assigned severity score of $0(n=31)$ and Mice group with assigned severity score $\geq 1(n=9)$} \\
\hline & Cut-off value (ng/g) & Sensitivity (\%) & Specificity (\%) & + PV (\%) & - PV (\%) & $P$ value \\
\hline Total $\mathrm{F}_{2}$-IsoPs & $>11.2$ & 100.00 & 90.32 & 75 & 100 & $<0.0001$ \\
\hline Total $\mathrm{F}_{2}$-dihomo-IsoPs & $>3.1$ & 88.89 & 80.65 & 57.1 & 96.2 & $<0.0001$ \\
\hline $4-\mathrm{F}_{4 \mathrm{t}}-\mathrm{NeuroP}$ & $>3.9$ & 66.67 & 100 & 100 & 91.2 & $<0.0001$ \\
\hline $10-\mathrm{F}_{4 \mathrm{t}}-$ NeuroP & $>7.9$ & 100 & 61.29 & 42.9 & 100 & $<0.0001$ \\
\hline Total $\mathrm{F}_{4}$-NeuroPs & $>10.6$ & 100 & 64.52 & 45.0 & 100 & $<0.0001$ \\
\hline
\end{tabular}

+P.V.: positive predictive value; -P.V.: negative predictive value.

disease severity was highlighted. In fact, $4 \mathrm{~F}_{4 \mathrm{t}}$-NeuroP was closely related to the disease parameters. This observation suggests the relevance of a brain gray matter damage and the differentiation between disease phenotypes, in particular when comparing the heterozygous mice with homozygous twitcher mice.

Studies showed an alteration of the brain matter in KD was associated to unexpected neuronal defects and myoclonic seizures [58,59]. Moreover, a distinctive feature for the proposed relationship between PUFA oxidative process and pathogenetic pathways appears to be confirmed by the different abundance of the two distinct $\mathrm{F}_{4}$-NeuroP isomers $\left(4-\mathrm{F}_{4 \mathrm{t}}-\mathrm{NeuroP}\right.$ and $\left.10-\mathrm{F}_{4 \mathrm{t}}-\mathrm{NeuroP}\right)$. Previously, it was reported that in vivo DHA oxidation follows preferential chemical rearrangements according to different neurological diseases. In particular, plasma levels of $4-\mathrm{F}_{4 \mathrm{t}}$-NeuroP and $10-\mathrm{F}_{4 \mathrm{t}}-\mathrm{NeuroP}$ were shown to be related to clinical severity of these diseases (multiple sclerosis, autism spectrum disorders, Rett syndrome, and Down syndrome) and distinctive for different neurological conditions [38]. In the investigated KD mouse model, $10-\mathrm{F}_{4 \mathrm{t}}-\mathrm{NeuroP}$ appears to be the preferential $\mathrm{F}_{4}$-NeuroP isomer to be formed in the brain DHA oxidation process of the twitcher mice.

Intriguingly, $\mathrm{F}_{2}$-dihomo-IsoP levels were distinctively elevated in twitcher mice but not in wild-type and heterozygous mice. Thus, $\mathrm{F}_{2^{-}}$ dihomo-IsoP levels appear to be a biochemical data to reflect the degree of the brain white matter damage, by oxidative stress and plausible to be a contributing factor of $\mathrm{KD}$ symptomatology. It is suggested that $\mathrm{F}_{2^{-}}$ dihomo-IsoPs may be a novel marker for gene-related diseases, where we found it to represent an early marker of the disease in Rett Syndrome, a pervasive neurodevelopment disorder mainly caused by mutations in the methyl-CpG binding protein 2 (MeCP2) gene [39]. Moreover, different from $\mathrm{KD}$, no significant changes of $\mathrm{F}_{2}$-dihomo-IsoP levels in brain tissue were observed in symptomatic Mecp2 $-/ \mathrm{y}$ mice, where an increased PUFA oxidation was revealed in the neurons but not in astrocytes [37].

A further interesting fact stemming from the present study is the significant increase in $\mathrm{F}_{2}$-IsoP and $\mathrm{F}_{4}$-NeuroP levels in the brain of heterozygous mice as it seems to be asymptomatic. In reference to the autosomal recessive disease, the severity score for heterozygotes mice was comparable to that reported for wild-type mice. A possible explanation for the difference in oxidative stress markers between wildtype and heterozygotes groups is that isoprostanoids appeared to be a part of the phenotype that mirrors KD severity when a cut off value is reached. Therefore, our observation in the increased levels of non-enzymatic PUFA products is not pre-empting when considering other recessive genetic disorders. Although carriers of recessive mutations are not clinically ill, altered clinical features and biochemical values can be evidenced. Within this context, high serum creatine kinase levels are reported in majority of dystrophinopathy carriers and cardiomyopathy can be detected in female carriers without any symptoms [60]. Likewise, minor individuals of thalassemia are generally considered healthy. Nevertheless, the prognosis of thalassemia minor carriers is suggested to be affected by iron overload and anaemia [61], features of thalassemia related to oxidative stress [62,63]. Indeed, thalassemia carriers are identifiable using red cell indices [64] and screening for thalassemia is based on a complete blood count and hemoglobin characterization [65]. When considering $\mathrm{KD}$, the reported increased damage to AA and DHA in twitcher mice agree with the update of a quite recent review showing that heterozygous carriers of KD-causing mutations exhibit increased risk of developing other complications such as multiple sclerosis [66]. This could confirm the hypothesis that the formation of isoprostanoids below a certain threshold value may not lead to immediate symptomatology but on the long term may be involved in development of other pathogenesis.

Although antioxidant treatments have been suggested to be able to counteract the psychosine damage and $\mathrm{KD}$ disease progression $[48,49,67]$, potential therapeutic perspective could be viewed from the role of isoprostanoids in eliciting different molecular mechanism pathways $[27,68]$. Insofar, it is known that isoprostanes mediate biological effects by interacting with prostanoid receptors, such as thromboxane receptor $[68,69]$.

In conclusion, a key role for PUFA oxidative damage to brain gray and white matter in the pathogenesis and progression of $\mathrm{KD}$ is reported shedding new insights on the biochemical indexes of KD and providing novel information for potential therapeutic targets.

\section{Funding}

This study was partially supported by Italian Association for Leucodistrophy of Krabbe "Progetto Grazia", and by funds for basic research "Ruolo dello stress ossidativo e di molecole antiossidanti nella sindrome di Rett".

The funders had no role in study design, data collection and analysis, decision to publish, or preparation of the manuscript.

\section{Acknowledgments}

This research is dedicated to Krabbe disease patients and their families.

\section{Appendix A. Supplementary data}

Supplementary data to this article can be found online at https:// doi.org/10.1016/j.freeradbiomed.2019.05.014.

\section{References}

[1] D.A. Wenger, M.A. Rafi, P. Luzi, Krabbe disease: one Hundred years from the bedside to the bench to the bedside, J. Neurosci. Res. 94 (2016) 982-989.

[2] J.S. Won, A.K. Singh, I. Singh, Biochemical, cell biological, pathological, and therapeutic aspects of Krabbe's disease, J. Neurosci. Res. 94 (2016) 990-1006.

[3] K.H. Cho, M.W. Kim, S.U. Kim, Tissue culture model of Krabbe's disease: psychosine cytotoxicity in rat oligodendrocyte cultures, Dev. Neurosci. 19 (1997) 321-327.

[4] S. Sugama, S.U. Kim, H. Ida, Y. Eto, Psychosine cytotoxicity in rat neural cell cultures and protection by phorbol ester and dimethyl sulfoxide, Pediatr. Res. 28 (1990) 473-476.

[5] R. Avola, A.C. Graziano, G. Pannuzzo, E. Alvares, V. Cardile, Krabbe's leukodystrophy: approaches and models in vitro, J. Neurosci. Res. 94 (2016) 1284-1292.

[6] S. Giri, M. Khan, R. Rattan, I. Singh, A.K. Singh, Krabbe disease: psychosinemediated activation of phospholipase A2 in oligodendrocyte cell death, J. Lipid Res. 47 (2006) 1478-1492.

[7] H. Bentsen, Dietary polyunsaturated fatty acids, brain function and mental health, Microb. Ecol. Health Dis. 28 (sup1) (2017) 1281916. 
[8] T. Wysoczański, E. Sokoła-Wysoczańska, J. Pękala, S. Lochyński, K. Czyż, R. Bodkowski, G. Herbinger, B. Patkowska-Sokoła, T. Librowski, Omega-3 fatty acids and their role in central nervous system - a review, Curr. Med. Chem. 23 (2016) 816-831.

[9] D.J. Bos, S.J. van Montfort, B. Oranje, S. Durston, P.A. Smeets, Effects of omega-3 polyunsaturated fatty acids on human brain morphology and function: what is the evidence? Eur. Neuropsychopharmacol. 26 (2016) 546-561.

[10] R. Crupi, A. Marino, S. Cuzzocrea, n-3 fatty acids: role in neurogenesis and neuroplasticity, Curr. Med. Chem. 20 (2013) 2953-2963.

[11] K.B. Hadley, A.S. Ryan, S. Forsyth, The essentiality of arachidonic acid in infant development, Nutrients 8 (2016) 216

[12] C.I. Janssen, A.J. Kiliaan, Long-chain polyunsaturated fatty acids (LCPUFA) from genesis to senescence: the influence of LCPUFA on neural development, aging, and neurodegeneration, Prog. Lipid Res. 53 (2014) 1-17.

[13] E. Kawakita, M. Hashimoto, O. Shido, Docosahexaenoic acid promotes neurogenesis in vitro and in vivo, Neuroscience 139 (2006) 991-997.

[14] S.E. Hancock, M.G. Friedrich, T.W. Mitchell, R.J. Truscott, P.L. Else, Decreases in phospholipids containing adrenic and arachidonic acids occur in the human Hippocampus over the adult lifespan, Lipids 50 (2015) 861-872.

[15] A.C. Graziano, V. Cardile, History, genetic, and recent advances on Krabbe disease, Gene 555 (2015) 2-13.

[16] A. Zanfini, E. Dreassi, A. Berardi, P. Piomboni, E. Costantino-Ceccarini, A. Luddi, GC-EI-MS analysis of fatty acid composition in brain and serum of twitcher mouse, Lipids 49 (2014) 1115-1125.

[17] C. Signorini, C. De Felice, J.M. Galano, C. Oger, S. Leoncini, A. Cortelazzo L. Ciccoli, T. Durand, J. Hayek, J.C. Lee, Isoprostanoids in clinical and experimental neurological disease models, Antioxidants (Basel) 7 (2018) E88.

[18] C. Signorini, C. De Felice, T. Durand, C. Oger, J.M. Galano, S. Leoncini, A. Pecorelli, G. Valacchi, L. Ciccoli, J. Hayek, Isoprostanes and 4-hydroxy-2-nonenal: markers or mediators of disease? Focus on Rett syndrome as a model of autism spectrum disorder, 2013, Oxid. Med. Cell. Longev. 2013 (2013) 34382410 pages http://dx.doi. org $/ 10.1155 / 2013 / 343824$.

[19] T. Durand, C. De Felice, C. Signorini, C. Oger, V. Bultel-Poncé, A. Guy, J.M. Galano, S. Leoncini, L. Ciccoli, A. Pecorelli, G. Valacchi, J. Hayekk, F(2)-Dihomo-isoprostanes and brain white matter damage in stage 1 Rett syndrome, Biochimie 95 (2013) 86-90.

[20] L. Joumard-Cubizolles, J.C. Lee, C. Vigor, H.H. Leung, J. Bertrand-Michel, J.M. Galano, A. Mazur, T. Durand, C. Gladine, Insight into the contribution of isoprostanoids to the health effects of omega 3 PUFAs, Prostag. Other Lipid Mediat. 133 (2017) 111-122.

[21] M. Czerska, M. Zieliński, J. Gromadzińska, Isoprostanes - a novel major group of oxidative stress markers, Int. J. Occup. Med. Environ. Health 29 (2016) 179-190.

[22] J.M. Galano, J.C. Lee, C. Gladine, B. Comte, J.Y. Le Guennec, C. Oger, T. Durand Non-enzymatic cyclic oxygenated metabolites of adrenic, docosahexaenoic, eicosapentaenoic and $\alpha$-linolenic acids; bioactivities and potential use as biomarkers, Biochim. Biophys. Acta 1851 (2015) 446-455.

[23] L. Minghetti, R. Salvi, M. Lavinia Salvatori, M.A. Ajmone-Cat, C. De Nuccio, S. Visentin, V. Bultel-Poncé, C. Oger, A. Guy, J.M. Galano, A. Greco, A. Bernardo, T. Durand, Nonenzymatic oxygenated metabolites of $\alpha$-linolenic acid B1- and L1phytoprostanes protect immature neurons from oxidant injury and promote differentiation of oligodendrocyte progenitors through PPAR- $\gamma$ activation, Free Radic. Biol. Med. 73 (2014) 41-50.

[24] J. Roy, J. Fauconnier, C. Oger, C. Farah, C. Angebault-Prouteau, J. Thireau, P. Bideaux, V. Scheuermann, V. Bultel-Poncé, M. Demion, J.M. Galano, T. Durand, J.C. Lee, J.Y. Le Guennec, Non-enzymatic oxidized metabolite of DHA, 4(RS)-4-F (4t)-neuroprostane protects the heart against reperfusion injury, Free Radic. Biol. Med. 102 (2017) 229-239.

[25] M. VanRollins, R.L. Woltjer, H. Yin, J.D. Morrow, T.J. Montine, F2-dihomo-isoprostanes arise from free radical attack on adrenic acid, J. Lipid Res. 49 (2008) 995-1005.

[26] E.E. Reich, W.R. Markesbery, L.J. Roberts 2nd, L.L. Swift, J.D. Morrow, T.J. Montine, Brain regional quantification of F-ring and D-/E-ring isoprostanes and neuroprostanes in Alzheimer's disease, Am. J. Pathol. 158 (2001) 293-297.

[27] E. Miller, A. Morel, L. Saso, J. Saluk, Isoprostanes and neuroprostanes as biomarkers of oxidative stress in neurodegenerative diseases, Oxid. Med. Cell. Longev. 2014 (2014) 572491.

[28] P.S. Sastry, Lipids of nervous tissue: composition and metabolism, Prog. Lipid Res. 24 (1985) 69-176.

[29] J.A. Hawkins-Salsbury, E.Y. Qin, A.S. Reddy, C.A. Vogler, M.S. Sands, Oxidative stress as a therapeutic target in globoid cell leukodystrophy, Exp. Neurol. 237 (2012) 444-452.

[30] E. Cavalca, M. Cesani, J.C. Gifford, M. Sena-Esteves, M.R. Terreni, G. Leoncini, M. Peviani, A. Biffi, Metallothioneins are neuroprotective agents in lysosomal storage disorders, Ann. Neurol. 83 (2018) 418-432.

[31] A. Del Grosso, S. Antonini, L. Angella, I. Tonazzini, G. Signore, M. Cecchini, Lithium improves cell viability in psychosine-treated MO3.13 human oligodendrocyte cell line via autophagy activation, J. Neurosci. Res. 94 (2016) 1246-1260.

[32] N.I. Weinstock, L. Wrabetz, M.L. Feltri, D. Shin, Metabolic profiling reveals biochemical pathways and potential biomarkers associated with the pathogenesis of Krabbe disease, J. Neurosci. Res. 94 (2016) 1094-1107.

[33] T. Kobayashi, T. Yamanaka, J.M. Jacobs, F. Teixeira, K. Suzuki, The Twitcher mouse: an enzymatically authentic model of human globoid cell leukodystrophy (Krabbe disease), Brain Res. 202 (1980) 479-483.

[34] N. Sakai, K. Inui, N. Tatsumi, H. Fukushima, T. Nishigaki, M. Taniike, J. Nishimoto, H. Tsukamoto, I. Yanagihara, K. Ozono, S. Okada, Molecular cloning and expression of cDNA for murine galactocerebrosidase and mutation analysis of the twitcher mouse, a model of Krabbe's disease, J. Neurochem. 66 (1996) 1118-1124.

[35] K. Suzuki, K. Suzuki, The twitcher mouse: a model for Krabbe disease and for experimental therapies, Brain Pathol. 5 (1995) 249-258.

[36] C. Signorini, L. Ciccoli, S. Leoncini, S. Carloni, S. Perrone, M. Comporti, W. Balduini, G. Buonocore, Free iron, total F-isoprostanes and total F-neuroprostanes in a model of neonatal hypoxic-ischemic encephalopathy: neuroprotective effect of melatonin, J. Pineal Res. 46 (2009) 148-154.

[37] C. De Felice, F. Della Ragione, C. Signorini, S. Leoncini, A. Pecorelli, L. Ciccoli, F. Scalabrì, F. Marracino, M. Madonna, G. Belmonte, L. Ricceri, B. De Filippis, G. Laviola, G. Valacchi, T. Durand, J.M. Galano, C. Oger, A. Guy, V. Bultel-Poncé, J. Guy, S. Filosa, J. Hayek, M. D'Esposito, Oxidative brain damage in Mecp2-mutant murine models of Rett syndrome, Neurobiol. Dis. 68 (2014) 66-77.

[38] C. Signorini, C. De Felice, T. Durand, J.M. Galano, C. Oger, S. Leoncini, L. Ciccoli, M. Carone, M. Ulivelli, C. Manna, A. Cortelazzo, J.C. Lee, J. Hayek, Relevance of 4-F (4t)-neuroprostane and 10-F(4t)-neuroprostane to neurological diseases, Free Radic. Biol. Med. 115 (2018) 278-287.

[39] C. De Felice, C. Signorini, T. Durand, C. Oger, A. Guy, V. Bultel-Poncé, J.M. Galano, L. Ciccoli, S. Leoncini, M. D'Esposito, S. Filosa, A. Pecorelli, G. Valacchi, J. Hayek, F2-dihomo-isoprostanes as potential early biomarkers of lipid oxidative damage in Rett syndrome, J. Lipid Res. 52 (2011) 2287-2297.

[40] C. Oger, V. Bultel-Poncé, A. Guy, L. Balas, J.C. Rossi, T. Durand, J.M. Galano, The handy use of Brown's P2-Ni catalyst for a skipped diyne deuteration: application to the synthesis of a [D4]-labeled F4t-neuroprostane, Chemistry 16 (2010) 13976-13980.

[41] A. Guy, C. Oger, J. Heppekausen, C. Signorini, C. De Felice, A. Fürstner, T. Durand, J.M. Galano, Oxygenated metabolites of n-3 polyunsaturated fatty acids as potential oxidative stress biomarkers: total synthesis of 8-F3t-IsoP, 10-F4t-NeuroP and [D4]10-F4t-NeuroP, Chemistry 20 (2014) 6374-6380.

[42] J.M. Galano, Y.Y. Lee, C. Oger, C. Vigor, J. Vercauteren, T. Durand, M. Giera, J.C. Lee, Isoprostanes, neuroprostanes and phytoprostanes: an overview of 25 years of research in chemistry and biology, Prog. Lipid Res. 68 (2017) 83-108.

[43] S. Karumuthil-Melethil, S.J. Gray, Immunological considerations for treating globoid cell leukodystrophy, J. Neurosci. Res. 94 (2016) 1349-1358.

[44] G.B. Potter, M.A. Petryniak, Neuroimmune mechanisms in Krabbe's disease, J. Neurosci. Res. 94 (2016) 1341-1348.

[45] M.E. Figueiredo-Pereira, P. Rockwell, T. Schmidt-Glenewinkel, P. Serrano, Neuroinflammation and J2 prostaglandins: linking impairment of the ubiquitinproteasome pathway and mitochondria to neurodegeneration, Front. Mol. Neurosci. 7 (2015) 104.

[46] S.M. Raefsky, R. Furman, G. Milne, E. Pollock, P. Axelsen, M.P. Mattson, M.S. Shchepinov, Deuterated polyunsaturated fatty acids reduce brain lipid peroxidation and hippocampal amyloid $\beta$-peptide levels, without discernible behavioral effects in an APP/PS1 mutant transgenic mouse model of Alzheimer's disease, Neurobiol. Aging 66 (2018) 165-176.

[47] W. Maruyama, M. Shaomoto-Nagai, Y. Kato, S. Hisaka, T. Osawa, M. Naoi, Role of lipid peroxide in the neurodegenerative disorders, in: Y. Kato (Ed.), Lipid Hydroperoxide-Derived Modification of Biomolecules. Subcellular Biochemistry, Springer, Dordrecht, 2014, pp. 127-136.

[48] E. Haq, S. Giri, I. Singh, A.K. Singh, Molecular mechanism of psychosine-induced cell death in human oligodendrocyte cell line, J. Neurochem. 86 (2003) 1428-1440.

[49] M. Khan, E. Haq, S. Giri, I. Singh, A.K. Singh, Peroxisomal participation in psychosine-mediated toxicity: implications for Krabbe's disease, J. Neurosci. Res. 80 (2005) 845-854.

[50] G.L. Milne, Q. Dai, L.J. Roberts 2nd, The isoprostanes-25 years later, Biochim. Biophys. Acta 1851 (2015) 433-445.

[51] C. Signorini, C. De Felice, S. Leoncini, R.S. Møller, G. Zollo, S. Buoni, A. Cortelazzo, R. Guerranti, T. Durand, L. Ciccoli, M. D'Esposito, K. Ravn, J. Hayek, MECP2 duplication syndrome: evidence of enhanced oxidative stress. A comparison with Rett syndrome, PLoS One 11 (2016) e0150101.

[52] S.W. Esch, T.D. Williams, S. Biswas, A. Chakrabarty, S.M. LeVine, Sphingolipid profile in the CNS of the twitcher (globoid cell leukodystrophy) mouse: a lipidomics approach, Cell. Mol. Biol. (Noisy-Le-Grand) 49 (2003) 779-787.

[53] H. Tokuda, M. Kontani, H. Kawashima, Differential effect of arachidonic acid and docosahexaenoic acid on age-related decreases in hippocampal neurogenesis, Neurosci. Res. 88 (2014) 58-66.

[54] F. Darios, B. Davletov, Omega-3 and omega-6 fatty acids stimulate cell membrane expansion by acting on syntaxin 3, Nature 440 (2006) 813-817.

[55] S. Chalon, S. Vancassel, L. Zimmer, D. Guilloteau, G. Durand, Polyunsaturated fatty acids and cerebral function: focus on monoaminergic neurotransmission, Lipids 36 (2001) 937-944.

[56] L. Colombaioni, M. Garcia-Gil, Sphingolipid metabolites in neural signalling and function, Brain Res. Rev. 46 (2004) 328-355.

[57] V. Filippov, M.A. Song, K. Zhang, H.V. Vinters, S. Tung, W.M. Kirsch, J. Yang, P.J. Duerksen-Hughes, Increased ceramide in brains with Alzheimer's and other neurodegenerative diseases, J. Alzheimer's Dis. 29 (2012) 537-547.

[58] E.R. Bongarzone, M.L. Escolar, S.J. Gray, T. Kafri, C.H. Vite, M.S. Sands, Insights into the pathogenesis and treatment of Krabbe disease, Pediatr. Endocrinol. Rev. 13 (Suppl 1) (2016) 689-696.

[59] L.E. Morse, N.P. Rosman, Myoclonic seizures in Krabbe disease: a unique presentation in late-onset type, Pediatr. Neurol. 35 (2006) 154-157.

[60] K. Adachi, S. Hashiguchi, M. Saito, S. Kashiwagi, T. Miyazaki, H. Kawai, H. Yamada, T. Iwase, M. Akaike, S. Takao, M. Kobayashi, M. Ishizaki, T. Matsumura, M. MoriYoshimura, E. Kimura, Detection and management of cardiomyopathy in female dystrophinopathy carriers, J. Neurol. Sci. 386 (2018) 74-80.

[61] L. Graffeo, A. Vitrano, S. Scondotto, G. Dardanoni, W.S. Pollina Addario, A. Giambona, M. Sacco, R. Di Maggio, D. Renda, F. Taormina, A. Triveri, 
M. Attanasio, C. Gluud, A. Maggio, $\beta$-Thalassemia heterozygote state detrimentally affects health expectation, Eur. J. Intern. Med. 54 (2018) 76-80.

[62] L. Ciccoli, C. Signorini, C. Scarano, V. Rossi, S. Bambagioni, M. Ferrali,

M. Comporti, Iron release in erythrocytes from patients with beta-thalassemia, Free Radic. Res. 30 (1999) 407-413.

[63] C. Matayatsuk, C.Y. Lee, R.W. Kalpravidh, P. Sirankapracha, P. Wilairat, S. Fucharoen, B. Halliwell, Elevated F2-isoprostanes in thalassemic patients, Free Radic. Biol. Med. 43 (2007) 1649-1655.

[64] O. Tangvarasittichai, N. Poonanan, S. Tangvarasittichai, Using red cell indices and reticulocyte parameters for carrier screening of various thalassemia syndromes, Indian J. Clin. Biochem. 32 (2017) 61-67.

[65] S. Langlois, J.C. Ford, D. Chitayat, CCMG prenatal diagnosis committee; sogc genetics committee, carrier screening for thalassemia and hemoglobinopathies in Canada, J. Obstet. Gynaecol. Can. 30 (2008) 950-959.

[66] N.J. Scott-Hewitt, C.J. Folts, M.D. Noble, Heterozygous carriers of galactocerebrosidase mutations that cause Krabbe disease have impaired microglial function and defective repair of myelin damage, Neural Regen. Res. 13 (2018) 393-401.

[67] G. Pannuzzo, V. Cardile, E. Costantino-Ceccarini, E. Alvares, D. Mazzone, V. Perciavalle, A galactose-free diet enriched in soy isoflavones and antioxidants results in delayed onset of symptoms of Krabbe disease in twitcher mice, Mol. Genet. Metab. 100 (2010) 234-2340.

[68] J.M. Galano, E. Mas, A. Barden, T.A. Mori, C. Signorini, C. De Felice, A. Barrett, C. Opere, E. Pinot, E. Schwedhelm, R. Benndorf, J. Roy, J.Y. Le Guennec, C. Oger, T. Durand, Isoprostanes and neuroprostanes: total synthesis, biological activity and biomarkers of oxidative stress in humans, Prostag. Other Lipid Mediat. 107 (2013) 95-102.

[69] E. Lauretti, A. Di Meco, J. Chu, D. Praticò, Modulation of AD neuropathology and memory impairments by the isoprostane F $2 \alpha$ is mediated by the thromboxane receptor, Neurobiol. Aging 36 (2015) 812-820. 